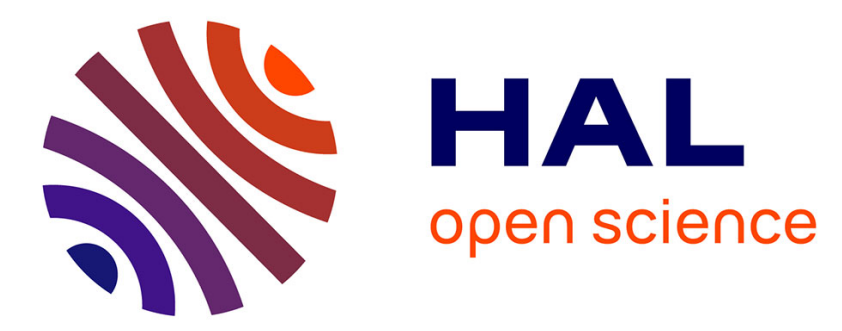

\title{
BNIP3 protects HepG2 cells against etoposide-induced cell death under hypoxia by an autophagy-independent pathway
}

Jean-Philippe Cosse, Guillaume Rommelaere, Noelle Ninane, Thierry Arnould, Carine Michiels

\section{To cite this version:}

Jean-Philippe Cosse, Guillaume Rommelaere, Noelle Ninane, Thierry Arnould, Carine Michiels. BNIP3 protects HepG2 cells against etoposide-induced cell death under hypoxia by an autophagyindependent pathway. Biochemical Pharmacology, 2010, 80 (8), pp.1160. 10.1016/j.bcp.2010.07.009 . hal-00618178

\section{HAL Id: hal-00618178 https://hal.science/hal-00618178}

Submitted on 1 Sep 2011

HAL is a multi-disciplinary open access archive for the deposit and dissemination of scientific research documents, whether they are published or not. The documents may come from teaching and research institutions in France or abroad, or from public or private research centers.
L'archive ouverte pluridisciplinaire HAL, est destinée au dépôt et à la diffusion de documents scientifiques de niveau recherche, publiés ou non, émanant des établissements d'enseignement et de recherche français ou étrangers, des laboratoires publics ou privés. 


\section{Accepted Manuscript}

Title: BNIP3 protects HepG2 cells against etoposide-induced cell death under hypoxia by an autophagy-independent pathway

Authors: Jean-Philippe Cosse, Guillaume Rommelaere, Noelle Ninane, Thierry Arnould, Carine Michiels

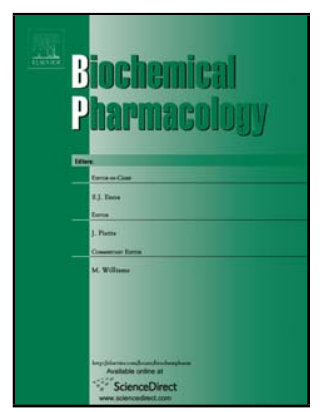

PII: S0006-2952(10)00520-4

DOI: doi:10.1016/j.bcp.2010.07.009

Reference: BCP 10642

To appear in: $\quad B C P$

Received date: $\quad$ 2-6-2010

Revised date: $\quad$ 2-7-2010

Accepted date: $\quad$ 6-7-2010

Please cite this article as: Cosse J-P, Rommelaere G, Ninane N, Arnould T, Michiels C, BNIP3 protects HepG2 cells against etoposide-induced cell death under hypoxia by an autophagy-independent pathway, Biochemical Pharmacology (2010), doi:10.1016/j.bcp.2010.07.009

This is a PDF file of an unedited manuscript that has been accepted for publication. As a service to our customers we are providing this early version of the manuscript. The manuscript will undergo copyediting, typesetting, and review of the resulting proof before it is published in its final form. Please note that during the production process errors may be discovered which could affect the content, and all legal disclaimers that apply to the journal pertain. 
BNIP3 protects HepG2 cells against etoposide-induced cell death under hypoxia by an autophagy-independent pathway

Authors: COSSE Jean-Philippe, ROMMELAERE Guillaume, NINANE Noelle, ARNOULD Thierry, MICHIELS Carine*

Affiliation : Laboratory of Biochemistry and Cellular Biology (URBC), NARILIS - NAmur Research Institute for LIfe Science, FUNDP-University of Namur, 61 rue de Bruxelles, 5000 Namur, Belgium

- corresponding author : URBC, FUNDP-University of Namur, 61 rue de Bruxelles, 5000 Namur Belgium, Email address : carine.michiels@fundp.ac.be ; tel 32-81724131, fax 32-81-724135 


\begin{abstract}
Tumor hypoxia is a common characteristic of most solid tumors and is correlated with poor prognosis for patients partly because hypoxia promotes resistance to cancer therapy. Hypoxia selects cancer cells that are resistant to apoptosis and allows the onset of mechanisms that promote cancer cells survival including autophagy. Previously, we showed that human hepatoma HepG2 cells were protected under hypoxia against the etoposide-induced apoptosis. In this study, respective putative contribution of autophagy and BNIP3 in the protection conferred by hypoxia against the etoposide-induced apoptosis was investigated. We report that autophagy is induced by etoposide, a process that is not affected by hypoxic conditions. Using Atg5 siRNA, we show that etoposide-induced autophagy promotes apoptotic cell death under normoxia but not under hypoxia. Then, we investigated whether the hypoxia-induced protein BNIP3 could explain the different effect of autophagy on cell death under hypoxia or normoxia. We show that the silencing of BNIP3 does not affect autophagy whatever the $\mathrm{pO}_{2}$ but participates in the protective effect of hypoxia against etoposide-induced apoptosis. Together, these results suggest that autophagy might be involved in etoposide-induced cell death only under normoxia and that BNIP3 is a major effector of the protective mechanism conferred by hypoxia to protect cancer cells against etoposide-induced apoptotic cell death.
\end{abstract}

Keywords : apoptosis, autophagy, BNIP3, hypoxia, cancer cells 


\section{Introduction}

Tumor hypoxia is recognized as a poor prognosis factor associated with resistance to cancer therapy such as radiotherapy and chemotherapy $[1,2]$. Inside the tumor, oxygen supply is compromised by the inadequate blood flow due to the abnormal vasculature network and by the high rate of cancer cell proliferation. Indeed, cancer cell proliferation also contributes to hypoxia by increasing the interstitial pressure and the diffusion distance from the blood vessels. Cancer cells localized in hypoxia areas are more resistant to chemotherapy than cells in well-oxygenated zones because drug delivery in hypoxia areas is limited and because oxygen is required for the cytotoxicity of some drugs [3]. Besides direct effects, hypoxia also promotes cancer cell resistance against chemotherapy by inducing adaptive mechanisms to hypoxia [4]. Regulation of gene expression, involving HIF-1, is an important component of the initiation of these adaptive responses to hypoxia. HIF-1 regulates the expression of over a hundred of genes and among them are genes encoding proteins involved in the regulation of angiogenesis, erythropoiesis, anaerobic metabolism, drug resistance and proliferation. In addition, cell survival and cell death are both regulated by hypoxia, in part through the regulation of programmed cell death I and II processes named apoptosis and autophagy respectively. The regulation of apoptosis by hypoxia involves the regulation of the expression of genes such as Bid, Bax, Noxa, Survivin and Mcl-1 [5-8]. In addition, hypoxia selects cancer cells with reduced apoptotic potential [9]. Autophagy is first a cellular response in which proteins, organelles and portions of cytoplasm are engulfed, digested and recycled to sustain cellular metabolism during stress such as nutrient starvation and hypoxia [10]. Although stimulation of autophagy might constitute a protective response, extensive and non regulated autophagy may lead to cell death which may be either independent or linked to apoptosis [11]. 
Under hypoxia, the induction of autophagy is mainly due to the hypoxia-inducible protein BNIP3, encoded by a HIF-1 target gene. BNIP3 belongs to the BH3-only Bcl-2 family and contains a BH3 domain and a transmembrane domain that targets BNIP3 to the outer mitochondrial membrane. Unlike other BH3-only proteins, interactions with other proteins as well as its functions depend on the transmembrane domain but not on the $\mathrm{BH} 3$ domain [12]. Before its role in autophagy was discovered, BNIP3 was associated with cell death by multiple mechanisms. Currently, it seems that BNIP3 may participate in cell death by inducing necrosis, apoptosis or autophagy. In some cases, localization of BNIP3 into the outer mitochondrial membrane causes an increase in ROS production, cytochrome c release by PTP opening, loss of $\Delta \Psi \mathrm{m}$ and leads to caspase-dependent cell death [13]. Bax and Bak seem to be essential for BNIP3-induced cell death characterized by apoptosis features [14]. Caspaseindependent cell death through the release of endoG but not of cytochrome c was also observed following BNIP3 insertion into the outer mitochondrial membrane [15]. Finally, BNIP3 can also induce autophagic cell death. However, the precise mechanisms involved are still poorly understood. It seems that BNIP3 could be involved in autophagosome-lysosome fusion or in earlier stages such as Beclin-1 activation and mTOR inhibition $[10,16,17]$. Finally, BNIP3 has been linked to protective autophagy and cell survival $[10,18]$.

We have previously shown that human hepatoma HepG2 cells could be protected against etoposide-induced apoptosis under hypoxia. Given the potential role of both autophagy and BNIP3 in the regulation of cell death and cell survival, we investigated their putative role in etoposide-induced cell death and the protection provided by hypoxia. 


\section{Material and Methods}

\subsection{Cell culture and hypoxia incubation}

Human hepatoma HepG2 cells were maintained in culture in $75-\mathrm{cm}^{2}$ polystyrene flasks (Costar, Lowell, USA) with 15 ml Dulbecco's modified Eagle's medium liquid (DMEM, Invitrogen, Carlsbad, USA)) and 10\% of foetal calf serum (Invitrogen, Carlsbad, USA) and incubated under an atmosphere containing $5 \% \mathrm{CO}_{2}$. For hypoxia experiments $\left(1 \% \mathrm{O}_{2}\right)$, cells were incubated in serum-free $\mathrm{CO}_{2}$-independent medium (Invitrogen, Carlsbad, USA) supplemented with $1 \mathrm{mM}$ L-glutamine (Sigma, St Louis, USA) with or without etoposide (Sigma, St Louis, USA) at $50 \mu \mathrm{M}$. Normoxic control cells were incubated in the same conditions but in normal atmosphere $\left(21 \% \mathrm{O}_{2}\right)$. For some experiments, bafilomycin $\mathrm{A} 1(100$ nM) (Sigma, St Louis, USA), thapsigargin ( $1 \mu \mathrm{M})$ (Sigma, St Louis, USA) or cycloheximide $(200 \mu \mathrm{M})($ Sigma, St Louis, USA) was added to medium.

\subsection{Visualization of DAPI-labelled nucleus}

40,000 cells were seeded on glass coverslips in 24-well culture plates. At the end of the incubation in serum-free $\mathrm{CO}_{2}$-independent medium (Invitrogen, Carlsbad, USA) supplemented with $1 \mathrm{mM}$ L-glutamine (Sigma, St Louis, USA) with or without etoposide (Sigma, St Louis, USA) at $50 \mu \mathrm{M}$, under hypoxia or under normoxia, medium was removed and cells were fixed for 10 min with PBS containing 4\% paraformaldehyde and then washed $3 \times 5$ min in PBS. Cells were then permeabilized with $0.2 \%$ Triton X-100 in PBS. After 5 min, $5 \mu$ of DAPI $(10 \mu \mathrm{g} / \mathrm{ml})$ (Sigma, St Louis, USA) were added in well. After $15 \mathrm{~min}$ of incubation in dark at $37^{\circ} \mathrm{C}$, diluted DAPI was removed and cells were washed with PBS. Then, the coverslips were mounted in Mowiol (Sigma, St Louis, USA) and observed with a fluorescent microscope.

\subsection{Western blotting}


Cells, seeded in $25 \mathrm{~cm}^{2}$ flasks, were scrapped in $200 \mu$ of lysis buffer ( $40 \mathrm{mM}$ Tris $\mathrm{pH} 7.5$, $150 \mathrm{mM} \mathrm{KCl}, 1 \mathrm{mM}$ EDTA, $1 \%$ triton X-100) containing a protease inhibitor mixture (« Complete » from Roche Molecular Biochemicals, Bsael, Switzerland, 1 tablet in $2 \mathrm{ml} \mathrm{H}_{2} \mathrm{O}$, added at a 1: 25 dilution) and phosphatase inhibitors (25 $\mathrm{mM} \mathrm{NaVO}, 250 \mathrm{mM}$ paranitrophenyl phosphate, $250 \mathrm{mM} \alpha$-glycerophosphate and $125 \mathrm{mM} \mathrm{NaF}$, at a $1: 25$ dilution). Western blot analysis was performed as described in Piret et al. [8] using a mouse anti-PARP-1 monoclonal antibody (\#556493 from Pharmingen, BD Biosciences, San Diego, USA), antibodies directed against Caspase-3 (\#9664 from Cell Signaling, Danvers, USA), LC3 (0231-100/LC3-5F10 from Nanotools, Teningen, Germany), Atg5 (\#2630S from Cell Signaling, Danvers, USAZ), BNIP3 (B7931 from Sigma, St Louis, USA), p62/SQSTM1 (H00008878-M03 from Abnova, Tapei, Taiwan) were used at 1:5000 dilution. Membranes were reprobed with $\alpha$-tubulin antibody (Sigma, St Louis, USA, final dilution $1 / 50,000$ ) or with $\beta$-actin antibody (Sigma, St Louis, USA, final dilution $1 / 50,000$ ) for protein loading control.

\subsection{Transmission electron microscopy}

Cells were fixed with $2.5 \%$ glutaraldehyde in $0.1 \mathrm{M}$ sodium cacodylate $(\mathrm{pH} 7.4)$ during 90 min, postfixed overnight in $1 \%$ osmium tetroxide in $0.1 \mathrm{M}$ sodium cacodylate $(\mathrm{pH} 7.4$ ), dehydrated in a graduated series of ethanol and embedded in LX 112 resin. Blocks were cut on an ultramicrotome (NOVA, LKB, El Cajon, USA) to obtain $40 \mathrm{~nm}$ sections. Sections were stained with uranyl acetate and observed on a Tecnaï 10 transmission electron microscope (Tecnaï 10, FEI, Hillsboro, USA)

\subsection{Quantification of MDC-labelled vacuoles}

Autophagic vacuoles were labelled with monodansylcadaverine (MDC, Sigma, St Louis, USA) by incubating cells with $0.05 \mathrm{mM} \mathrm{MDC}$ in $\mathrm{PBS}$ at $37^{\circ} \mathrm{C}$ for $15 \mathrm{~min}$. After this 
incubation, cells were washed four times in PBS and the fluorescence associated with MDC uptake by autophagic vacuoles was measured by excitation at $380 \mathrm{~nm}$ and emission at $450 \mathrm{~nm}$ with a fluorometer (Perkin Elmer LS45 fluorescence spectrometer, Zaventem, Belgium). The protein concentration was measured and fluorescent value was normalized by total amount of proteins.

\subsection{Transient transfection with LC3-GFP}

HepG2 cells were seeded in $75-\mathrm{cm}^{2}$ polystyrene flasks (Costar, Lowell, USA) at a density of $6.10^{6}$ on day 0 . On day 2 , HepG2 cells were transfected with an expression plasmid pEGFPLC3m encoding GFP-LC3 (from Professor Bassam Janji, LHCE CRP-Santé, Luxembourg) $(2 \mu \mathrm{g} / \mathrm{ml})$ and using Lipofectamine 2000 (Invitrogen, Carlsbad, USA) (3 $\mu \mathrm{l} / \mu \mathrm{g}$ DNA) as a transfection agent for $4 \mathrm{~h}$. At the end of this incubation, transfection medium was replaced by fresh medium containing $10 \%$ of foetal calf serum. On day 3 , cells were trypsinized and 40,000 cells were seeded on glass coverslips in 24 -well culture plates. On day 4, medium was replaced by serum-free $\mathrm{CO}_{2}$-independent medium (Invitrogen, Carlsbad, USA) supplemented with $1 \mathrm{mM}$ L-glutamine (Sigma, , St Louis, USA) with or without etoposide (Sigma, , St Louis, USA) at $50 \mu \mathrm{M}$ and cells were incubated under hypoxia or under normoxia during $16 \mathrm{~h}$. At the end of this incubation, medium was removed and cells were fixed for 10 min with PBS containing 4\% paraformaldehyde and then washed $3 \times 5$ min with PBS. To visualize nuclei, cells were incubated at room temperature for $35 \mathrm{~min}$ in the presence of TO-PRO-3 (Invitrogen, Carlsbad, USA, 1:80 dilution in PBS + RNase $2 \mathrm{mg} / \mathrm{ml}$ ). After 3 washes in PBS, the coverslips were mounted in Mowiol (Sigma, St Louis, USA) and observed with a confocal fluorescent microscope (SP2, Leica, Mannheim, Germany).

\subsection{Short interfering RNA transfection}


The siGENOME smartpool of siRNA BNIP3 (M-004636-01) and Atg5 (M-004374-04) were obtained from Dharmacon (Lafayette, USA). siGENOME smartpool of siRNA were transfected with the DharmaFECT1 transfection reagent (Dharmacon, T-2001, Lafayette, USA) according to the manufacturer's recommendations. Cells seeded at 40,000 cells $/ \mathrm{cm}^{2}$ were incubated with transfection medium for $24 \mathrm{~h}$. After this incubation, transfection medium was replaced by fresh medium with $10 \%$ of foetal calf serum. DharmaFECT1 was used at a final dilution 1:500 and siRNA were used at $50 \mathrm{nM}$. siCONTROL RISC free (D-001220-01) siRNA were used as negative control.

\subsection{Caspase-3 activity assay}

The fluorogenic substrate Ac-DEVD-AFC (BD Biosciences, San Diego, USA) was used to measure caspase-3 activity according to Lozano et al [19]. Cell extracts were prepared as described by Wellington et al [20]. Cells were seeded in 6-well plates (250,000 cells/well). The assay for caspase-3 activity was performed according to Cosse et al [21].

\section{$L D H$ release assay}

LDH release was measured with the cytotoxicity detection kit from Roche Molecular Biochemical (Basel, Switzerland) according to the manufacturer's protocol.

\subsection{Real time RT-PCR}

At the end of the incubation, total RNA was extracted using the Trizol extraction kit (Invitrogen, Carlsbad, USA). mRNA contained in $2 \mu \mathrm{g}$ total RNA was reverse transcribed using SuperScript II Reverse Transcriptase (Invitrogen, Carlsbad, USA) according to the manufacturer's instructions. Forward and reverse primers for BNIP3 and RPL13A were designed using the Primer Express 1.5 software (Applied Biosystem, Carlsbad, USA) (23kDHBP-F : $\quad$ GCCTACAAGAAAGTTTGCCTATCTG/23kDHBP-R 
TGAGCTGTTTCTTCTTCCGGTAGT ; BNIP3-F : TTTGCTGGCCATCGGATT/BNIP3-R : ACCAAGTCAGACTCCAGTTCTTCA). Amplification reaction assays contained 1x SYBR Green PCR Mastermix (Applied Biosystem, Carlsbad, USA) and primers (Applied Biosystem, Carlsbad, USA) at the optimal concentrations. RPL13A was used as the reference gene for normalization and mRNA expression level was quantified using the threshold cycle method.

\subsection{Statistical analysis}

Statistical analyses were performed using Student's t test using SigmaStat software (Jandel Scientific Software). For each set of data, real triplicates were performed in one experiment. 


\section{Results}

\subsection{Hypoxia protects HepG2 cells against etoposide-induced apoptosis}

We have previously shown that hypoxia protects HepG2 cells against etoposide-induced apoptosis [21-23]. To confirm these results, cells were incubated for $16 \mathrm{~h}$ in serum freemedium in the presence or in the absence of etoposide, under normoxia $\left(21 \% \mathrm{O}_{2}\right)$ or under hypoxia $\left(1 \% \mathrm{O}_{2}\right)$. At the end of the incubation, cells were fixed and nuclei were labelled with DAPI and observed with fluorescent microscopy (Figure 1A). We observed nuclear fragmentation in cells exposed to etoposide under normoxia but not in cells exposed to etoposide under hypoxia nor in cells that were not incubated with etoposide whatever the $\mathrm{pO}_{2}$. In addition, the cleavage of PARP-1 was assessed by Western blot (Figure 1B). Etoposide induced the cleavage of PARP-1 and hypoxia prevented the cleavage of the protein. Hypoxia per se had no effect on the cleavage of PARP-1. In conclusion, as previously shown, etoposide induces apoptosis while hypoxia, a condition that does not affect apoptosis, protects cells against etoposide-induced apoptotic cell death.

\subsection{Effects of hypoxia and/or etoposide on autophagy}

Autophagy is known to be a cellular response to energy-limiting stresses such as serum deprivation. Moreover, it has been described that some chemotherapeutic drugs can also induce autophagy $[24,25]$. In order to evaluate the effect of hypoxia and/or etoposide on autophagy, cells were incubated for $16 \mathrm{~h}$ with or without etoposide under normoxia or under hypoxia. At the end of the incubation, the presence of autophagic vacuoles was assessed using transmission electron microscopy (Figure 2A). Despite being incubated 16 hours in serumfree medium, basal autophagy induced by these conditions remained low (Figure 2A, Nx). We observed that etoposide increased the number of autophagosomes in cells treated with etoposide both under normoxia and under hypoxia. In addition, the incorporation of the 
autofluorescent marker Monodansylcadaverine (MDC) has been assessed (Figure 2B). MDC was first described as a specific marker of autophagic vacuoles [26, 27]. However, subsequent studies have suggested that MDC is not a specific marker for early autophagosomes $[28,29]$. We observed that the MDC-associated fluorescence was higher in cells treated with etoposide than in control cells. Very low difference was observed between cells under hypoxia and cells under normoxia, independently of the presence of etoposide. To confirm these results, the conversion of LC3-I to LC3-II has been investigated. LC3 is the human homolog of yeast Atg8. LC3-I is obtained by the cleavage of nascent LC3 (proLC3) by Atg4 and is located in cytosol. During autophagy, LC3-I is involved in the formation of autophagosome and is incorporated into the autophagic vacuole membrane. For this, LC3-I must be conjugated to phosphatidylethanolamine (PE) by Atg7. PE-conjugated LC3-I is called LC3-II [30]. Although the molecular weight of LC3-II is larger than the weight of LC3-I due to the conjugation to PE, LC3-II migrates faster than LC3-I in SDS-PAGE due to its higher hydrophobicity. Therefore, LC3-I and LC3-II are usually detected in SDS-PAGE at a molecular mass around $16 \mathrm{kDa}$ and $14 \mathrm{kDa}$ respectively [31]. Cellular extracts were prepared from cells incubated with or without etoposide, under normoxia or under hypoxia for a period ranging from 2 to 24 hours and the level of both forms of LC3 was assessed by Western blot (Figure 3A). Etoposide induced the conversion of LC3-I to LC3-II under normoxia between 8 and 24 hours. Surprisingly, hypoxia did not induce the conversion of LC3-I to LC3-II. After 16 hours of incubation, the abundance of total LC3 drastically decreased in cells exposed to hypoxia. As a positive control, cells were treated with thapsigargin, a well-known inducer of autophagy. We observed that thapsigargin promoted the conversion of LC3-I to LC3-II and also increased the abundance of total LC3. These results indicate that etoposide is capable of inducing both apoptosis and autophagy. To determine the sequence of apoptotic and autophagic responses induced by etoposide, cleavage of PARP-1 was studied together with 
the conversion of LC3-I into LC3-II. The cleavage of PARP-1 protein was not detectable before 16 hours of incubation with etoposide, whereas the conversion of LC3-I into LC3-II was already observed after 8 hours of incubation. It has to be noted that LC3-II abundance then decreased. This result indicates that the activation of autophagy by etoposide occurs before the induction of apoptosis (Figure 3A). To study the LC3 relocalization in membrane of autophagic vacuoles, cells transiently transfected with GFP-tagged LC3 were used (Figure 3B). After 16 hours of incubation with or without etoposide under hypoxia or under normoxia, cells were fixed, nuclei were stained with TO-PRO-3 and cells were observed in a confocal fluorescent microscope to determine the localization of LC3-GFP. During autophagy, LC3-II is recruited to the autophagic vacuoles membrane giving a punctuate labelling. Such labelling was observed in cells incubated in the presence of etoposide under normoxia, while it was more diffuse in etoposide-incubated cells under hypoxia as well as in control cells whatever the $\mathrm{pO}_{2}$. Under hypoxia, the abundance of total LC3 decreased as previously observed by Western blot. It is known that LC3-II is located both in the inner and the outer membrane of autophagic vacuoles [32]. After autophagosome-lysosome fusion, the fraction of LC3-II that is located in the inner membrane is degraded while the fraction of LC3-II located in the outer membrane is released in the cytosol and converted back in LC3-I, so the decrease of total LC3 protein level may be due to a higher autophagic rate. However, we did not observe any differences between autophagy under hypoxia and autophagy under normoxia in the presence of etoposide although the rate of autophagy is difficult to assess through the conversion of LC3 as long term exposure to hypoxia alters the abundance of the protein. In addition, following treatment with bafilomycin A1 which blocks autophagosomelysosome fusion, the abundance of total LC3 was higher in normoxic cells than in hypoxic cells (Figure 3C). This indicates that the difference in the abundance of total LC3 between normoxia and hypoxia was not due to change in the autophagic rate. Therefore, we postulated 
that this difference was the consequence of the inhibition of the cap-dependent translation under hypoxia. To test this hypothesis, cells were treated with cycloheximide to block protein synthesis (Figure 3D). We observed that the abundance of total LC3 is reduced under normoxia in cells treated with cycloheximide. This confirms our hypothesis that difference in LC3 level between normoxia and hypoxia was not due to a change in autophagic rate between these conditions but to a decrease in protein synthesis under hypoxia.

\subsection{Differential effect of etoposide-induced autophagy under normoxia compared to hypoxia}

We have shown that etoposide induced autophagy while hypoxia had no effect on the etoposide-induced autophagy. We have also evidenced that the resistance of HepG2 cells against etoposide is higher under hypoxia than under normoxia. The fact that the autophagic rate is independent of hypoxia does not exclude the involvement of autophagy in the difference in resistance to etoposide observed between normoxia and hypoxia as autophagy may be protective or may contribute to cell death. To determine the role of etoposide-induced autophagy in the modulation of etoposide-induced cell death under normoxia and under hypoxia, we inhibited autophagy using Atg5 small interfering RNA (siRNA). Atg5 is a component of the Atg12-Atg5 conjugation complex required for the formation of autophagosome. In this process that requires also $\operatorname{Atg} 7$ and $\operatorname{Atg} 10, \operatorname{Atg} 12$ is covalently linked to Atg5. The Atg12-Atg5 conjugation occurs prior the LC3-PE conjugation [30]. Atg5 protein and mRNA levels were reduced by over $80 \%$ in Atg5 siRNA-transfected cells (data not shown). To evaluate the effect of Atg5 silencing on etoposide-induced autophagy, cells were incubated for $16 \mathrm{~h}$ with or without etoposide under normoxia or under hypoxia and both the LC3-I and LC3-II abundance was assessed by Western blot. Atg5 siRNA decreased the conversion LC3-I to LC3-II since the LC3-I level was increased and the LC3-II level did not change or was even decreased in these conditions, indicating a slower autophagy (Figure 4A). It should be noted that the inhibition of autophagy by the silencing of Atg5 did not increase 
the total LC3 abundance under hypoxia to the total abundance of LC3 under normoxia, a data again supporting the fact that the lower total abundance of LC3 under hypoxia is independent of autophagy. Then, we studied the effect of autophagy inhibition on the etoposide-induced apoptosis by following caspase-3 activity using a fluorogenic substrate (Figure 4B). The cleavage of Ac-DEVD-AFC substrate was increased by etoposide while hypoxia inhibited these effects. Interestingly, the silencing of Atg5 reduced the cleavage of Ac-DEVD-AFC substrate under normoxia. In contrast, Atg5 silencing did not affect the cleavage of AcDEVD-AFC substrate under hypoxia. In conclusion, autophagy seems to promote etoposideinduced cell death markers of apoptosis under normoxia. By contrast, autophagy does not seem to affect the protective effect of hypoxia although, even if in some cases, it appears to have a weak protective effect. These results were confirmed by measuring overall viability. LDH release was investigated in cells incubated for 40 hours with etoposide (Figure 4C). Etoposide increased LDH release while hypoxia reduced the etoposide-induced LDH release. The silencing of Atg5 reduced the etoposide-induced LDH release under normoxia and did not modify the etoposide-induced LDH release under hypoxia, indicating that autophagy could promote etoposide-induced cell death under normoxia but would not have any effect under hypoxia. Generally, negative control siRNA had no or little influence on studied parameters. Altogether, these results indicate that autophagy does not modulate the protection against etoposide conferred by hypoxia.

3.4 Effect of BNIP3 on the resistance against etoposide-induced apoptosis under hypoxia

To explain why etoposide-induced autophagy does not have the same consequences under normoxia and under hypoxia, we investigated the role of BNIP3, a hypoxia-induced protein for which an involvement in autophagy has been clearly demonstrated [16]. BNIP3 is a BH3only protein encoded by a HIF-1-target gene [33]. As expected, the protein and mRNA levels of BNIP3 are increased under hypoxia in HepG2 (Figures 5A and 5B). In contrast, etoposide 
seemed to slightly reduce protein and mRNA levels but also to limit the upregulation of BNIP3 by hypoxia. BNIP3 has been associated with cell death by necrosis, apoptosis and autophagy. Moreover, a protective role has been conferred to BNIP3 in part through the upregulation of autophagy [10]. To determine the putative role of BNIP3 on autophagy and apoptosis in the protection conferred by hypoxia, the expression of BNIP3 was silenced using specific siRNA. A decrease in BNIP3 mRNA of $91 \%$ was observed under hypoxia (data not shown). The impact of the silencing of BNIP3 on autophagy was determined by assessing the abundance of LC3-I and LC3-II by Western blot (Figure 5C). BNIP3 silencing had no effect on the abundance of both forms of LC3, suggesting that it does not influence autophagy in these experimental conditions. The possible involvement of BNIP3 in apoptosis was determined by following caspase- 3 activity. We observed that caspase- 3 activity was not affected by the silencing of BNIP3 under normoxia (Figure 5D). In contrast, the silencing of BNIP3 induced a weak increase in active caspase-3 protein level in cells incubated in the presence of etoposide under hypoxia. In conclusion, we observed that the silencing of BNIP3 sensitized cells against etoposide-induced apoptosis under hypoxia while it had no effect on the etoposide-induced apoptosis under normoxia. To confirm these results, viability was assessed by measuring LDH release after 40 hours of incubation (Figure 5E). Etoposide increased LDH release and this was attenuated in hypoxic cells showing the protection conferred by hypoxia. There was no significant difference in etoposide-induced LDH release between control cells and cells transfected with BNIP3 siRNA under normoxia. In contrast, the etoposide-induced release is higher in BNIP3 siRNA-transfected cells than in control cells, indicating that BNIP3 is involved in the protective effect conferred by hypoxia. 


\section{Discussion}

Our recent studies have demonstrated that hypoxia protects human hepatoma HepG2 cells against etoposide-induced apoptosis (Figures 1A and 1B) [8, 21-23]. Hypoxia is an energylimiting stress which ean leads to autophagy upregulation. Autophagy starts with the formation of an autophagosome, enclosed within a double membrane that engulfs part of cytoplasm. The formation of autophagosome depends upon Atg proteins [34]. Autophagy can be stimulated by various stresses, including nutrient depletion or hypoxia. In this case, autophagy is used to provide the constituents required to maintain metabolism essential for cell survival or to promote cell death, suggesting a dual role of autophagy [35-37]. Connections between autophagy and apoptosis have been identified. It has been shown that autophagy can either collaborate with apoptosis either to promote cell death or to prevent apoptotic cell death [38-41].

Therefore, we sought to evaluate the role of autophagy in the etoposide-induced apoptosis and the protective effect of hypoxia on it. To evaluate the autophagic rate, autophagosomes were observed by transmission electron microscopy and MDC-labelling (Figures 2A and 2B). In addition, LC3-I and LC3-II protein level and localization of LC3-GFP were studied (Figures 3A and 3B). We observed that autophagy was enhanced by etoposide. The upregulation of autophagy by chemotherapeutic drugs has already been described [42-47]. Chemotherapyinduced autophagy may promote cell resistance against it. Doxorubicin-induced DNA damage stimulates cytoprotective autophagy through a PARP-1-dependent pathway [48]. Similarly, cisplatin-induced autophagy delays apoptosis in renal tubular epithelial cells [45] and tamoxifen and camptothecin-induced autophagy increases MCF7 breast carcinoma cell line viability $[42,46]$. Examples of autophagic cell death in response to chemotherapy were also described. Vitamin D analogue, EB1089, kills MCF7 through the induction of massive autophagy [43] while arsenic trioxide induces autophagic cell death in human malignant 
glioma cell lines [44]. Autophagic cell death is also an alternative cell death pathway to apoptosis when it is no longer functional. Indeed, etoposide-induced autophagic cell death was described in apoptosis-deficient mouse embryonic fibroblasts [47]. We then investigated the impact of hypoxia on the etoposide-induced apoptosis. The results showed that hypoxia had no effect by itself on autophagy and did not modify the etoposide-induced autophagy (Figures 3A and 3B). This is surprising and inconsistent with the literature in which the regulation of autophagy by hypoxia is well documented. Indeed, Papandreou et al. have shown that hypoxia induces autophagy through the AMPK activation [49] but the main mechanism of induction of autophagy by hypoxia requires HIF-1 and BNIP3 $[10,16]$. The reason of this discrepancy is not known. It is however known that the level of $\mathrm{pO}_{2}$ may influence the induction of autophagy by hypoxia [50].

Although the etoposide-induced autophagy rate under normoxia and under hypoxia was similar, it is conceivable that autophagy plays a role in the protective effect of hypoxia. As mentioned previously, autophagy can lead to cell death, possibly by cooperating with apoptosis, or can promote cell survival by providing the constituents required to maintain metabolism essential for survival. Furthermore, autophagy may antagonize apoptosis through the elimination of depolarized mitochondria to prevent the release of apoptogenic factors such as AIF and cytochrome $\mathrm{c}$ from damaged mitochondria $[35,38]$. To better delineate the role of autophagy in the etoposide-induced cell death and to determine whether or not there were differences between etoposide-induced autophagy under hypoxia and under normoxia, we inhibited autophagy. For this, Atg5 expression was silenced using specific siRNA. Atg5 is a component of the Atg12-Atg5 conjugation system required for the process of autophagosome formation. The effect of Atg5 silencing on autophagy was evaluated by studying the abundance of both forms of LC3. This marker of autophagy is appropriate to study the inhibition of autophagy due to Atg5 silencing since it has been shown that the LC3-I 
conversion to LC3-II was downstream the Atg12-Atg5 conjugation and required Atg5 [30]. The silencing of Atg5 inhibited autophagy as LC3-II level decreased and LC3-I level increased in these conditions (Figure 4A). To determine the effect of autophagy inhibition on etoposide-induced apoptosis, the activity of active caspase-3 as well as cell viability were studied (Figures 4B and C). Atg5 silencing reduced the etoposide-induced apoptosis under normoxia but did not influence it under hypoxia. This means that autophagy contributes to etoposide-induced apoptosis under normoxia and acts upstream of apoptosis. In contrast, autophagy had no effect neither on the etoposide-induced apoptosis under hypoxia, nor on the protection conferred by hypoxia. The inhibition of the expression of Atg5 gene with siRNA has already been reported to promote resistance to chemotherapy [51, 52]. However, it has been reported that Atg5 might be cleaved by calpains and truncated Atg5 could stimulate apoptosis by direct interaction with Bcl-XL in the mitochondrial outer membrane [53]. We can not exclude this possibility.

BNIP3 is a BH3-only Bcl2 family member encoded by a HIF-1 target gene [33]. Many studies have reported that BNIP3 expression induces cell death with features that are both consistent and inconsistent with apoptosis suggesting that BNIP3 induces cell death through multiple pathways including apoptosis, necrosis and autophagy according to cell lines and conditions [13-15, 44]. Indeed, BNIP3-induced cell death is related to mitochondrial dysfunction, membrane depolarization, permeability transition pore opening and increased generation of ROS according to the experimental conditions. Both caspase-dependent and caspase-independent forms of cell death have been related to BNIP3. In some cases, BNIP3induced cell death was associated with the appearance of autophagic vacuoles and cellular morphological features of necrosis [54]. On the other hand, BNIP3-induced autophagy was described as a survival mechanism, providing time and resources for cell adaptation. Zhang et al. showed that BNIP3-induced mitochondrial autophagy promotes cell survival under 
hypoxia by preventing an increase in ROS levels [10]. Bcl-2 family pro-survival members inhibit autophagy by sequestering Beclin-1, a protein required for initiating autophagy [55]. Indeed, BNIP3 promotes autophagy by displacing Beclin-1 from Bcl-2 [10]. The involvement of BNIP3 in other steps of autophagy has also been described. It seems that BNIP3 can induce autophagy by interacting with RheB, resulting in mTOR inhibition [17]. Moreover, the involvement of BNIP3 in later stages of autophagy, such as autophagosome-lysosome fusion, has also been described [16]. In this work, we have studied the involvement of BNIP3 in the protective effect of hypoxia against apoptosis for several reasons. First, the expression of BNIP3 is linked to hypoxia and HIF-1 [33]. Secondly, BNIP3 is involved both in cell death as in cell survival $[10,13,14,54]$. Thirdly, BNIP3 is a connection between apoptosis and autophagy [10]. To study the role of BNIP3, the expression of BNIP3 was silenced using siRNA. The study of LC3-I and LC3-II proteins level showed that BNIP3 did not affect the etoposide-induced autophagy whatever the $\mathrm{pO}_{2}$ level (Figure 5C). Moreover, BNIP3 silencing had no effect on etoposide-induced apoptosis under normoxia as caspase-3 activity was not affected by BNIP3 silencing (Figure 5D). In contrast, BNIP3 silencing increased caspase-3 activity under hypoxia, indicating that BNIP3 is involved in the protection conferred by hypoxia against the etoposide-induced apoptosis. In the literature, the role of BNIP3 in cell survival is clearly linked to its function in regulating autophagy. However, in HepG2 cells with the experimental conditions used, we showed that the protective effect of BNIP3 is independent of autophagy. Similarly, a recent report mentioned a protective effect of BNIP3 by a mechanism independent on autophagy. Indeed, Burton et al. have shown that BNIP3 is located in the nucleus and acts as transcriptional repressor of apoptosis-inducing factor (AIF) gene, in association with PSF and HDAC1, in human glioma U251 and U87 cells [56]. Further studies are thus needed to investigate how BNIP3 can inhibit apoptosis under hypoxia. 
In conclusion, we observed that hypoxia protects HepG2 cells against etoposide-induced apoptosis by the induction of BNIP3. BNIP3 is shown to be induced by hypoxia by a HIF-1dependent manner and to promote autophagy that can lead to cell death or cell survival according to the experimental conditions. In HepG2 cells, we observed that autophagy is induced by etoposide but not by hypoxia. Moreover, we observed that autophagy has a dual role as it promotes etoposide-induced apoptosis under normoxia but not under hypoxia. Finally, we showed that BNIP3 does not regulate autophagy and protects HepG2 against etoposide-induced apoptosis by an autophagy-independent mechanism (Figure 6).

\section{Acknowledgements}

J.-P. Cosse is recipient of a FRIA fellowship (Fonds pour la formation à la Recherche dans l'Industrie et dans l'Agriculture). This article presents results of the Belgian program on Interuniversity Poles of Attraction initiated by the Belgian State, Prime Minister's Office, Science Policy Programming. The responsibility is assumed by its authors. We thank Prof. Bassam Janji (LHCE CRP-Santé, Luxembourg) for providing the pEGFP-LC3m plasmid and the department of electron microscopy (FUNDP). 


\section{References}

[1] Rockwell S. Oxygen delivery: implications for the biology and therapy of solid tumors Oncol Res 1997; 9:383-90.

[2] Vaupel P and Mayer A. Hypoxia and anemia: effects on tumor biology and treatment resistance Transfus Clin Biol 2005; 12:5-10.

[3] Tredan O, Galmarini CM, Patel K and Tannock IF. Drug resistance and the solid tumor microenvironment J Natl Cancer Inst 2007; 99:1441-54.

[4] Cosse JP and Michiels C. Tumour hypoxia affects the responsiveness of cancer cells to chemotherapy and promotes cancer progression Anticancer Agents Med Chem 2008; 8:790-7. [5] Erler JT, Cawthorne CJ, Williams KJ, Koritzinsky M, Wouters BG, Wilson C, Miller C, Demonacos C, Stratford IJ and Dive C. Hypoxia-mediated down-regulation of Bid and Bax in tumors occurs via hypoxia-inducible factor 1-dependent and -independent mechanisms and contributes to drug resistance Mol Cell Biol 2004; 24:2875-89.

[6] Kim JY, Ahn HJ, Ryu JH, Suk K and Park JH. BH3-only protein Noxa is a mediator of hypoxic cell death induced by hypoxia-inducible factor 1alpha J Exp Med 2004; 199:113-24. [7] Peng XH, Karna P, Cao Z, Jiang BH, Zhou M and Yang L. Cross-talk between epidermal growth factor receptor and hypoxia-inducible factor-1alpha signal pathways increases resistance to apoptosis by up-regulating survivin gene expression J Biol Chem 2006; 281:25903-14.

[8] Piret JP, Minet E, Cosse JP, Ninane N, Debacq C, Raes M and Michiels C. Hypoxiainducible factor-1-dependent overexpression of myeloid cell factor-1 protects hypoxic cells against tert-butyl hydroperoxide-induced apoptosis J Biol Chem 2005; 280:9336-44.

[9] Graeber TG, Osmanian C, Jacks T, Housman DE, Koch CJ, Lowe SW and Giaccia AJ. Hypoxia-mediated selection of cells with diminished apoptotic potential in solid tumours Nature 1996; 379:88-91. 
[10] Zhang H, Bosch-Marce M, Shimoda LA, Tan YS, Baek JH, Wesley JB, Gonzalez FJ and Semenza GL. Mitochondrial autophagy is an HIF-1-dependent adaptive metabolic response to hypoxia J Biol Chem 2008; 283:10892-903.

[11] Scarlatti F, Granata R, Meijer AJ and Codogno P. Does autophagy have a license to kill mammalian cells? Cell Death Differ 2009; 16:12-20.

[12] Chen G, Cizeau J, Vande Velde C, Park JH, Bozek G, Bolton J, Shi L, Dubik D and Greenberg A. Nix and Nip3 form a subfamily of pro-apoptotic mitochondrial proteins J Biol Chem 1999; 274:7-10.

[13] Regula KM, Ens K and Kirshenbaum LA. Inducible expression of BNIP3 provokes mitochondrial defects and hypoxia-mediated cell death of ventricular myocytes Circ Res 2002; 91:226-31.

[14] Kubli DA, Ycaza JE and Gustafsson AB. Bnip3 mediates mitochondrial dysfunction and cell death through Bax and Bak Biochem J 2007; 405:407-15.

[15] Zhang Z, Yang X, Zhang S, Ma X and Kong J. BNIP3 upregulation and EndoG translocation in delayed neuronal death in stroke and in hypoxia Stroke 2007; 38:1606-13.

[16] Azad MB, Chen Y, Henson ES, Cizeau J, McMillan-Ward E, Israels SJ and Gibson SB. Hypoxia induces autophagic cell death in apoptosis-competent cells through a mechanism involving BNIP3 Autophagy 2008; 4:195-204.

[17] Li Y, Wang Y, Kim E, Beemiller P, Wang CY, Swanson J, You M and Guan KL. Bnip3 mediates the hypoxia-induced inhibition on mammalian target of rapamycin by interacting with Rheb J Biol Chem 2007; 282:35803-13.

[18] Tracy K and Macleod KF. Regulation of mitochondrial integrity, autophagy and cell survival by BNIP3 Autophagy 2007; 3:616-9. 
[19] Lozano J, Menendez S, Morales A, Ehleiter D, Liao WC, Wagman R, Haimovitz-

Friedman A, Fuks Z and Kolesnick R. Cell autonomous apoptosis defects in acid sphingomyelinase knockout fibroblasts J Biol Chem 2001; 276:442-8.

[20] Wellington CL, Ellerby LM, Hackam AS, Margolis RL, Trifiro MA, Singaraja R, McCutcheon K, Salvesen GS, Propp SS, Bromm M, Rowland KJ, Zhang T, Rasper D, Roy S, Thornberry N, Pinsky L, Kakizuka A, Ross CA, Nicholson DW, Bredesen DE and Hayden MR. Caspase cleavage of gene products associated with triplet expansion disorders generates truncated fragments containing the polyglutamine tract J Biol Chem 1998; 273:9158-67.

[21] Cosse JP, Sermeus A, Vannuvel K, Ninane N, Raes M and Michiels C. Differential effects of hypoxia on etoposide-induced apoptosis according to the cancer cell lines Mol Cancer 2007; 6:61.

[22] Cosse JP, Ronvaux M, Ninane N, Raes MJ and Michiels C. Hypoxia-induced decrease in p53 protein level and increase in c-jun DNA binding activity results in cancer cell resistance to etoposide Neoplasia 2009; 11:976-86.

[23] Sermeus A, Cosse JP, Crespin M, Mainfroid V, de Longueville F, Ninane N, Raes M, Remacle J and Michiels C. Hypoxia induces protection against etoposide-induced apoptosis: molecular profiling of changes in gene expression and transcription factor activity Mol Cancer 2008; 7:27.

[24] Takeuchi H, Kondo Y, Fujiwara K, Kanzawa T, Aoki H, Mills GB and Kondo S. Synergistic augmentation of rapamycin-induced autophagy in malignant glioma cells by phosphatidylinositol 3-kinase/protein kinase B inhibitors Cancer Res 2005; 65:3336-46.

[25] Kanzawa T, Germano IM, Komata T, Ito H, Kondo Y and Kondo S. Role of autophagy in temozolomide-induced cytotoxicity for malignant glioma cells Cell Death Differ 2004; 11:448-57. 
[26] Biederbick A, Kern HF and Elsasser HP. Monodansylcadaverine (MDC) is a specific in vivo marker for autophagic vacuoles Eur J Cell Biol 1995; 66:3-14.

[27] Munafo DB and Colombo MI. A novel assay to study autophagy: regulation of autophagosome vacuole size by amino acid deprivation J Cell Sci 2001; 114:3619-29.

[28] Bampton ET, Goemans CG, Niranjan D, Mizushima N and Tolkovsky AM. The dynamics of autophagy visualized in live cells: from autophagosome formation to fusion with endo/lysosomes Autophagy 2005; 1:23-36.

[29] Klionsky DJ, Abeliovich H, Agostinis P, Agrawal DK, Aliev G, Askew DS, Baba M, Baehrecke EH, Bahr BA, Ballabio A, Bamber BA, Bassham DC, Bergamini E, Bi X, BiardPiechaczyk M, Blum JS, Bredesen DE, Brodsky JL, Brumell JH, Brunk UT, Bursch W, Camougrand N, Cebollero E, Cecconi F, Chen Y, Chin LS, Choi A, Chu CT, Chung J, Clarke PG, Clark RS, Clarke SG, Clave C, Cleveland JL, Codogno P, Colombo MI, Coto-Montes A, Cregg JM, Cuervo AM, Debnath J, Demarchi F, Dennis PB, Dennis PA, Deretic V, Devenish RJ, Di Sano F, Dice JF, Difiglia M, Dinesh-Kumar S, Distelhorst CW, Djavaheri-Mergny M, Dorsey FC, Droge W, Dron M, Dunn WA, Jr., Duszenko M, Eissa NT, Elazar Z, Esclatine A, Eskelinen EL, Fesus L, Finley KD, Fuentes JM, Fueyo J, Fujisaki K, Galliot B, Gao FB, Gewirtz DA, Gibson SB, Gohla A, Goldberg AL, Gonzalez R, Gonzalez-Estevez C, Gorski S, Gottlieb RA, Haussinger D, He YW, Heidenreich K, Hill JA, Hoyer-Hansen M, Hu X, Huang WP, Iwasaki A, Jaattela M, Jackson WT, Jiang X, Jin S, Johansen T, Jung JU, Kadowaki M, Kang C, Kelekar A, Kessel DH, Kiel JA, Kim HP, Kimchi A, Kinsella TJ, Kiselyov K, Kitamoto K, Knecht E, Komatsu M, Kominami E, Kondo S, Kovacs AL, Kroemer G, Kuan CY, Kumar R, Kundu M, Landry J, Laporte M, Le W, Lei HY, Lenardo MJ, Levine B, Lieberman A, Lim KL, Lin FC, Liou W, Liu LF, Lopez-Berestein G, Lopez-Otin C, Lu B, Macleod KF, Malorni W, Martinet W, Matsuoka K, Mautner J, Meijer AJ, Melendez A, Michels P, Miotto G, Mistiaen WP, Mizushima N, Mograbi B, Monastyrska I, Moore MN, 
Moreira PI, Moriyasu Y, Motyl T, Munz C, Murphy LO, Naqvi NI, Neufeld TP, Nishino I, Nixon RA, Noda T, Nurnberg B, Ogawa M, Oleinick NL, Olsen LJ, Ozpolat B, Paglin S, Palmer GE, Papassideri I, Parkes M, Perlmutter DH, Perry G, Piacentini M, Pinkas-Kramarski R, Prescott M, Proikas-Cezanne T, Raben N, Rami A, Reggiori F, Rohrer B, Rubinsztein DC, Ryan KM, Sadoshima J, Sakagami H, Sakai Y, Sandri M, Sasakawa C, Sass M, Schneider C, Seglen PO, Seleverstov O, Settleman J, Shacka JJ, Shapiro IM, Sibirny A, Silva-Zacarin EC, Simon HU, Simone C, Simonsen A, Smith MA, Spanel-Borowski K, Srinivas V, Steeves M, Stenmark H, Stromhaug PE, Subauste CS, Sugimoto S, Sulzer D, Suzuki T, Swanson MS, Tabas I, Takeshita F, Talbot NJ, Talloczy Z, Tanaka K, Tanida I, Taylor GS, Taylor JP, Terman A, Tettamanti G, Thompson CB, Thumm M, Tolkovsky AM, Tooze SA, Truant R, Tumanovska LV, Uchiyama Y, Ueno T, Uzcategui NL, van der Klei I, Vaquero EC, Vellai T, Vogel MW, Wang HG, Webster P, Wiley JW, Xi Z, Xiao G, Yahalom J, Yang JM, Yap G, Yin XM, Yoshimori T, Yu L, Yue Z, Yuzaki M, Zabirnyk O, Zheng X, Zhu X and Deter RL. Guidelines for the use and interpretation of assays for monitoring autophagy in higher eukaryotes Autophagy 2008; 4:151-75.

[30] Ichimura Y, Imamura Y, Emoto K, Umeda M, Noda T and Ohsumi Y. In vivo and in vitro reconstitution of Atg8 conjugation essential for autophagy J Biol Chem 2004; 279:40584-92.

[31] Mizushima N and Yoshimori T. How to interpret LC3 immunoblotting Autophagy 2007; $3: 542-5$

[32] Tanida I, Minematsu-Ikeguchi N, Ueno T and Kominami E. Lysosomal turnover, but not a cellular level, of endogenous LC3 is a marker for autophagy Autophagy 2005; 1:84-91.

[33] Sowter HM, Ratcliffe PJ, Watson P, Greenberg AH and Harris AL. HIF-1-dependent regulation of hypoxic induction of the cell death factors BNIP3 and NIX in human tumors Cancer Res 2001; 61:6669-73. 
[34] Yang YP, Liang ZQ, Gu ZL and Qin ZH. Molecular mechanism and regulation of autophagy Acta Pharmacol Sin 2005; 26:1421-34.

[35] Elmore SP, Qian T, Grissom SF and Lemasters JJ. The mitochondrial permeability transition initiates autophagy in rat hepatocytes FASEB J 2001; 15:2286-7.

[36] Clarke PG. Developmental cell death: morphological diversity and multiple mechanisms Anat Embryol (Berl) 1990; 181:195-213.

[37] Bursch W. The autophagosomal-lysosomal compartment in programmed cell death Cell Death Differ 2001; 8:569-81.

[38] Lemasters JJ, Nieminen AL, Qian T, Trost LC, Elmore SP, Nishimura Y, Crowe RA, Cascio WE, Bradham CA, Brenner DA and Herman B. The mitochondrial permeability transition in cell death: a common mechanism in necrosis, apoptosis and autophagy Biochim Biophys Acta 1998; 1366:177-96.

[39] Boya P, Gonzalez-Polo RA, Casares N, Perfettini JL, Dessen P, Larochette N, Metivier D, Meley D, Souquere S, Yoshimori T, Pierron G, Codogno P and Kroemer G. Inhibition of macroautophagy triggers apoptosis Mol Cell Biol 2005; 25:1025-40.

[40] Ravikumar B, Berger Z, Vacher C, O'Kane CJ and Rubinsztein DC. Rapamycin pretreatment protects against apoptosis Hum Mol Genet 2006; 15:1209-16.

[41] Espert L, Denizot M, Grimaldi M, Robert-Hebmann V, Gay B, Varbanov M, Codogno P and Biard-Piechaczyk M. Autophagy is involved in T cell death after binding of HIV-1 envelope proteins to CXCR4 J Clin Invest 2006; 116:2161-72.

[42] Abedin MJ, Wang D, McDonnell MA, Lehmann U and Kelekar A. Autophagy delays apoptotic death in breast cancer cells following DNA damage Cell Death Differ 2007; 14:500-10. 
[43] Hoyer-Hansen M, Bastholm L, Mathiasen IS, Elling F and Jaattela M. Vitamin D analog EB1089 triggers dramatic lysosomal changes and Beclin 1-mediated autophagic cell death Cell Death Differ 2005; 12:1297-309.

[44] Kanzawa T, Zhang L, Xiao L, Germano IM, Kondo Y and Kondo S. Arsenic trioxide induces autophagic cell death in malignant glioma cells by upregulation of mitochondrial cell death protein BNIP3 Oncogene 2005; 24:980-91.

[45] Kaushal GP, Kaushal V, Herzog C and Yang C. Autophagy delays apoptosis in renal tubular epithelial cells in cisplatin cytotoxicity Autophagy 2008; 4:710-2.

[46] Qadir MA, Kwok B, Dragowska WH, To KH, Le D, Bally MB and Gorski SM. Macroautophagy inhibition sensitizes tamoxifen-resistant breast cancer cells and enhances mitochondrial depolarization Breast Cancer Res Treat 2008; 112:389-403.

[47] Shimizu S, Kanaseki T, Mizushima N, Mizuta T, Arakawa-Kobayashi S, Thompson CB and Tsujimoto Y. Role of Bcl-2 family proteins in a non-apoptotic programmed cell death dependent on autophagy genes Nat Cell Biol 2004; 6:1221-8.

[48] Munoz-Gamez JA, Rodriguez-Vargas JM, Quiles-Perez R, Aguilar-Quesada R, MartinOliva D, de Murcia G, Menissier de Murcia J, Almendros A, Ruiz de Almodovar M and Oliver FJ. PARP-1 is involved in autophagy induced by DNA damage Autophagy 2009; 5:6174.

[49] Papandreou I, Lim AL, Laderoute K and Denko NC. Hypoxia signals autophagy in tumor cells via AMPK activity, independent of HIF-1, BNIP3, and BNIP3L Cell Death Differ $2008 ; 15: 1572-81$.

[50] Rouschop KM and Wouters BG. Regulation of autophagy through multiple independent hypoxic signaling pathways Curr Mol Med 2009; 9:417-24. 
[51] Longo L, Platini F, Scardino A, Alabiso O, Vasapollo G and Tessitore L. Autophagy inhibition enhances anthocyanin-induced apoptosis in hepatocellular carcinoma Mol Cancer Ther 2008; 7:2476-85.

[52] Yokoyama T, Miyazawa K, Naito M, Toyotake J, Tauchi T, Itoh M, Yuo A, Hayashi Y, Georgescu MM, Kondo Y, Kondo S and Ohyashiki K. Vitamin K2 induces autophagy and apoptosis simultaneously in leukemia cells Autophagy 2008; 4:629-40.

[53] Yousefi S, Perozzo R, Schmid I, Ziemiecki A, Schaffner T, Scapozza L, Brunner T and Simon HU. Calpain-mediated cleavage of Atg5 switches autophagy to apoptosis Nat Cell Biol 2006; 8:1124-32.

[54] Vande Velde C, Cizeau J, Dubik D, Alimonti J, Brown T, Israels S, Hakem R and Greenberg AH. BNIP3 and genetic control of necrosis-like cell death through the mitochondrial permeability transition pore Mol Cell Biol 2000; 20:5454-68.

[55] Pattingre S, Tassa A, Qu X, Garuti R, Liang XH, Mizushima N, Packer M, Schneider MD and Levine B. Bcl-2 antiapoptotic proteins inhibit Beclin 1-dependent autophagy Cell $2005 ; 122: 927-39$.

[56] Burton TR, Eisenstat DD and Gibson SB. BNIP3 (Bcl-2 $19 \mathrm{kDa}$ interacting protein) acts as transcriptional repressor of apoptosis-inducing factor expression preventing cell death in human malignant gliomas J Neurosci 2009; 29:4189-99. 


\section{Figure legends}

Figure 1: Hypoxia protects HepG2 cells against etoposide-induced apoptosis. HepG2 cells were incubated for 16 hours under normoxic $\left(\mathrm{Nx} ; 21 \% \mathrm{O}_{2}\right)$ or hypoxic $\left(\mathrm{Hx} ; 1 \% \mathrm{O}_{2}\right)$ conditions with $(\mathrm{Ne}-\mathrm{He})$ or without $(\mathrm{Nx}-\mathrm{Hx})$ etoposide $(50 \mu \mathrm{M})$. (A) Nuclear fragmentation was assessed by nuclei labeling with DAPI using non-confocal fluorescent microscope. Fragmented nuclei are pointed by yellow arrows. (B) PARP-1 cleavage was detected in total cell extracts by Western blot analysis, using a specific antibody. Immunodetection of $\alpha$ tubulin was used to assess the equal protein loading on the gel.

Figure 2: Etoposide increases the abundance of autophagic vacuoles. HepG2 cells were incubated for 16 hours under normoxic $\left(\mathrm{Nx} ; 21 \% \mathrm{O}_{2}\right)$ or hypoxic $\left(\mathrm{Hx} ; 1 \% \mathrm{O}_{2}\right)$ conditions with $(\mathrm{Ne}-\mathrm{He})$ or without $(\mathrm{Nx}-\mathrm{Hx})$ etoposide $(50 \mu \mathrm{M})$. (A) Cells were fixed in glutaraldehyde and postfixed in osmium tetroxide. Ultramicrotome sections were poststained and imaged on transmission electron microscope. (B) Autophagic vacuoles were labeled with fluorescent marker MDC and MDC-associated fluorescent was measured. Results are normalized by total amount of protein and are presented as means $\pm 1 \mathrm{SD}(\mathrm{n}=3)$. Statistical analysis was carried out with the Student's t test. ns : non significant; * : $0.05>\mathrm{P}>0.01 ; * * *: \mathrm{P}<0.001$.

Figure 3: Etoposide increased LC3-I conversion to LC3-II while hypoxia decreases total LC3 abundance. (A) HepG2 cells were incubated for increasing periods from 2 to 24 hours under normoxic $\left(\mathrm{Nx} ; 21 \% \mathrm{O}_{2}\right)$ or hypoxic $\left(\mathrm{Hx} ; 1 \% \mathrm{O}_{2}\right)$ conditions with $(\mathrm{Ne}-\mathrm{He} ; 50 \mu \mathrm{M})$ or without (Nx-Hx) etoposide $(50 \mu \mathrm{M})$. LC3 and PARP-1 were detected in total cell extracts by Western blot analysis, using specific antibody. Immunodetection of $\alpha$-tubulin was used to assess the equal protein loading on the gel. Thapsigargin was used as a positive control for autophagy. (B) LC3-GFP expressing cells were incubated for 16 hours under normoxic $\left(\mathrm{Nx} ; 21 \% \mathrm{O}_{2}\right)$ or hypoxic $\left(\mathrm{Hx} ; 1 \% \mathrm{O}_{2}\right)$ conditions with $(\mathrm{Ne}-\mathrm{He})$ or without $(\mathrm{Nx}-\mathrm{Hx})$ etoposide $(50 \mu \mathrm{M})$. At the 
end of the incubation, cells were fixed and nuclei were labeled with TO-PRO-3. Then, localization of LC3-GFP was studied using confocal fluorescent microscope. (C and D) Cells were incubated for 16 hours under normoxic $\left(\mathrm{Nx} ; 21 \% \mathrm{O}_{2}\right)$ or hypoxic $\left(\mathrm{Hx} ; 1 \% \mathrm{O}_{2}\right)$ conditions with $(\mathrm{Ne}-\mathrm{He})$ or without $(\mathrm{Nx}-\mathrm{Hx})$ etoposide $(50 \mu \mathrm{M})$. Bafilomycin A was used to block autophagy and cycloheximide (CHX) was used as a protein synthesis inhibitor. At the end of the incubation, LC3 was detected in total cell extracts by Western blot analysis, using specific antibody. Immunodetection of $\alpha$-tubulin or $\beta$-actin was used to assess the equal protein loading on the gel.

Figure 4: Etoposide-induced autophagy contributes to apoptosis and cell death under normoxia but not under hypoxia. HepG2 cells were transfected with Atg5 siRNA or negative control RISC free siRNA for 24 hours. Eight hours later, cells were incubated for 16 hours under normoxic $\left(\mathrm{Nx} ; 21 \% \mathrm{O}_{2}\right)$ or hypoxic $\left(\mathrm{Hx} ; 1 \% \mathrm{O}_{2}\right)$ conditions with $(\mathrm{Ne}-\mathrm{He})$ or without $(\mathrm{Nx}-\mathrm{Hx})$ etoposide $(50 \mu \mathrm{M})$. (A) At the end of the incubations, Atg5 and LC3 were detected in total cell extracts by Western blot analysis, using specific antibody. Immunodetection of $\beta$ actin was used to assess the equal protein loading on the gel. (B) Caspase-3 activity was assayed by measuring fluorescence intensity associated with free AFC released from the cleavage of the caspase-3 substrate Ac-DEVD-AFC. Results were normalized by fluorescence intensity of control cells and are presented as means $\pm 1 \mathrm{SD}(\mathrm{n}=3)$. (C) LDH release was assessed after 40 hours of incubation. Results were normalized by the LDH release of control cells and are presented as means $\pm 1 \mathrm{SD}(\mathrm{n}=3)$. Statistical analysis was carried out with the Student's t test. ns : non significant; * $: 0.05>\mathrm{P}>0.01 ; * *: 0.01>\mathrm{P}>0.001 ; * * * \mathrm{P}<0.001$.

Figure 5: BNIP3 has no effect on etoposide-induced autophagy and apoptosis under normoxia but protects against etoposide-induced apoptosis under hypoxia through an autophagyindependent pathway. (A and B) HepG2 cells were incubated for 16 hours under normoxic $\left(\mathrm{Nx} ; 21 \% \mathrm{O}_{2}\right)$ or hypoxic $\left(\mathrm{Hx} ; 1 \% \mathrm{O}_{2}\right)$ conditions with $(\mathrm{Ne}-\mathrm{He})$ or without $(\mathrm{Nx}-\mathrm{Hx})$ etoposide 
$(50 \mu \mathrm{M})$. (A) At the end of the incubation, total RNA was extracted, submitted to reverse transcription, and then to amplification in the presence of SYBR Green and specific primers for BNIP3. RPL13A was used as the housekeeping gene for data normalization. (B) BNIP3 was detected in total cell extracts by Western blot analysis, using specific antibody. $\alpha$-tubulin was used to assess the equal protein loading on the gel. (5C-5E) HepG2 cells were transfected with BNIP3 siRNA or negative control RISC free siRNA for 24 hours. Eight hours later, cells were incubated for 16 hours under normoxic $\left(\mathrm{Nx} ; 21 \% \mathrm{O}_{2}\right)$ or hypoxic $\left(\mathrm{Hx} ; 1 \% \mathrm{O}_{2}\right)$ conditions with $(\mathrm{Ne}-\mathrm{He})$ or without $(\mathrm{Nx}-\mathrm{Hx})$ etoposide $(50 \mu \mathrm{M})$. (C) At the end of the incubation LC3 was detected in total cell extracts by Western blot analysis, using specific antibodies. Immunodetection of $\beta$-actin was used to assess the equal protein loading on the gel. (D) Caspase-3 activity was assayed by measuring fluorescence intensity associated with free AFC released from the cleavage of the caspase-3 substrate Ac-DEVD-AFC. Results are normalized by fluorescence intensity of control cells and are presented as means \pm 1 SD ( $\mathrm{n}=$ 3). (E) LDH release was assessed after 40 hours of incubation. Results were normalized by the LDH release of control cells and are presented as means \pm 1 SD $(n=3)$. Statistical analysis was carried out with the Student's t test. ns : non significant; * $: 0.05>\mathrm{P}>0.01 ; * *$ : $0.01>\mathrm{P}>0.001 ; * * *: \mathrm{P}<0.001$

Figure 6: Schematic representation of the involvement of autophagy and BNIP3 on the etoposide-induced apoptosis and the protective effect conferred by hypoxia against it. Etoposide induces DNA double strand breaks (DSB) and causes apoptosis and cell death. Hypoxia protects cells against etoposide-induced apoptosis. Autophagy is induced by etoposide both in normoxic and hypoxic cells. In normoxic cells, autophagy contributes to etoposide-induced apoptotic cell death. In contrast, autophagy has no effect on etoposideinduced apoptotic cell death and on the protective effect conferred by hypoxia. BNIP3 is 
induced by hypoxia and is involved in the protective effect of hypoxia against etoposideinduced apoptosis but does not regulate autophagy. 
A
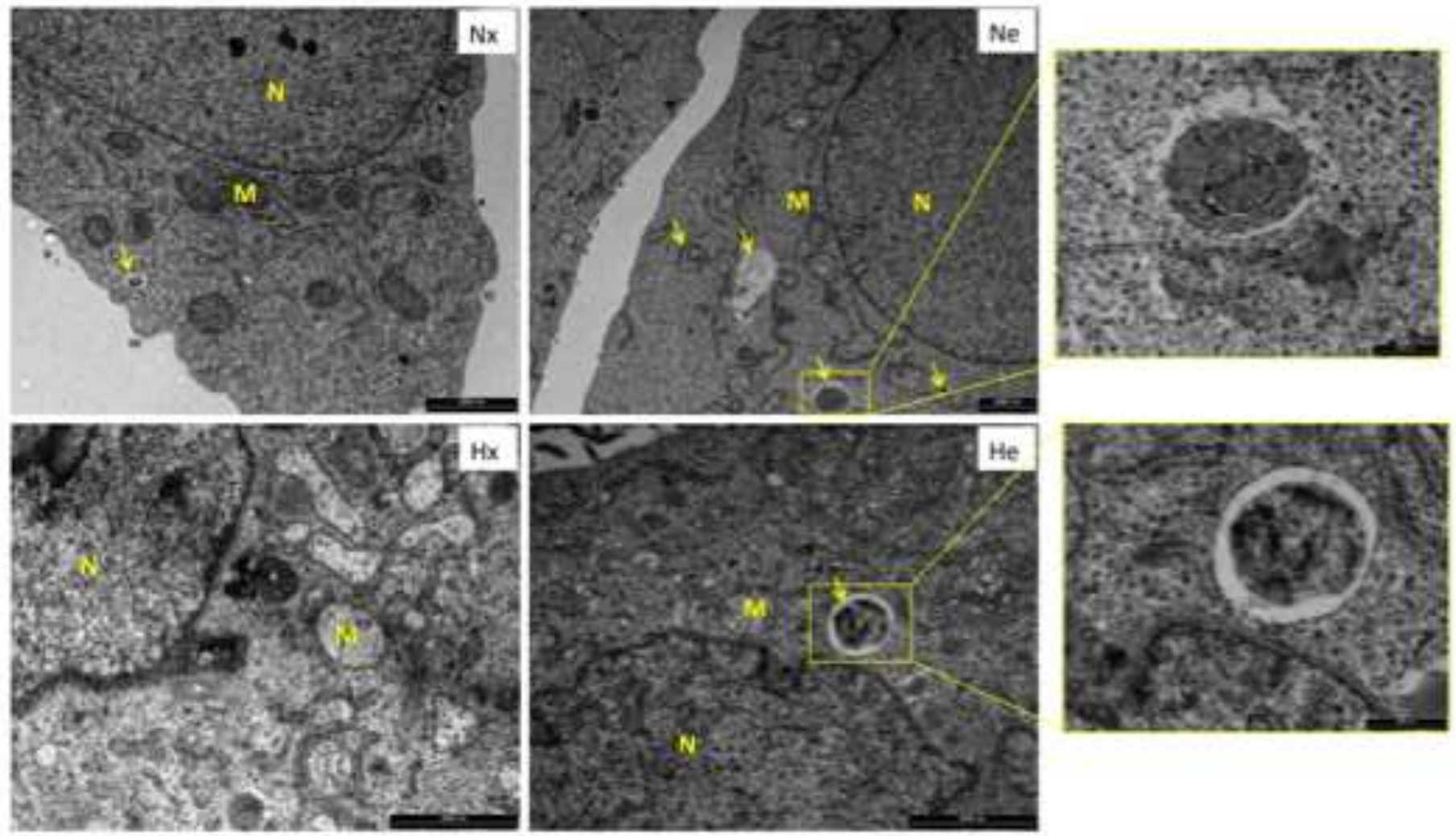

Figure 2

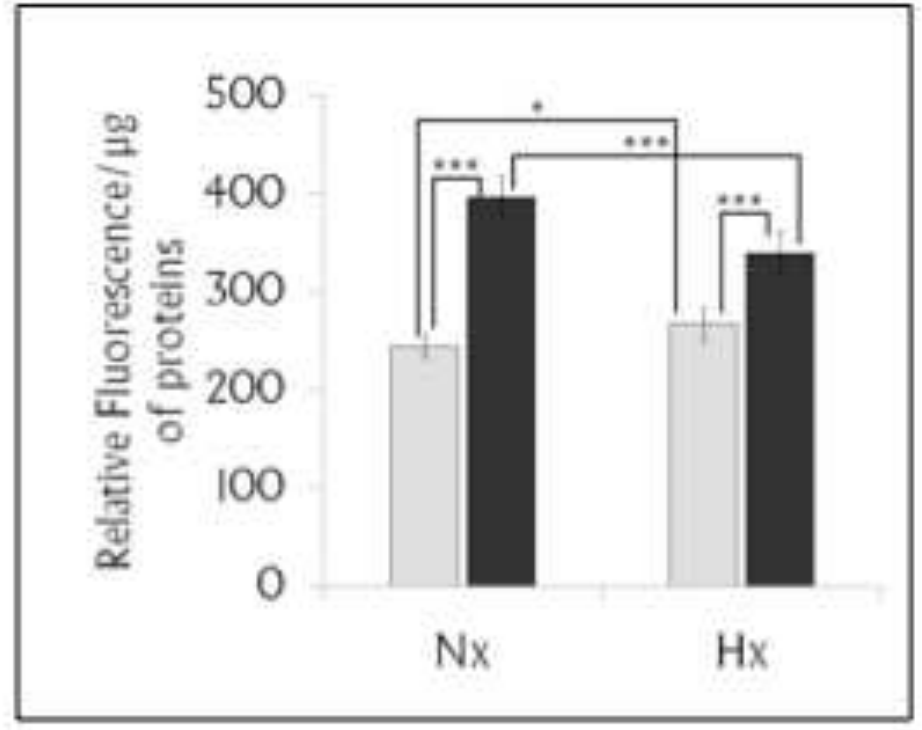

$\square$ Control

Etoposide 


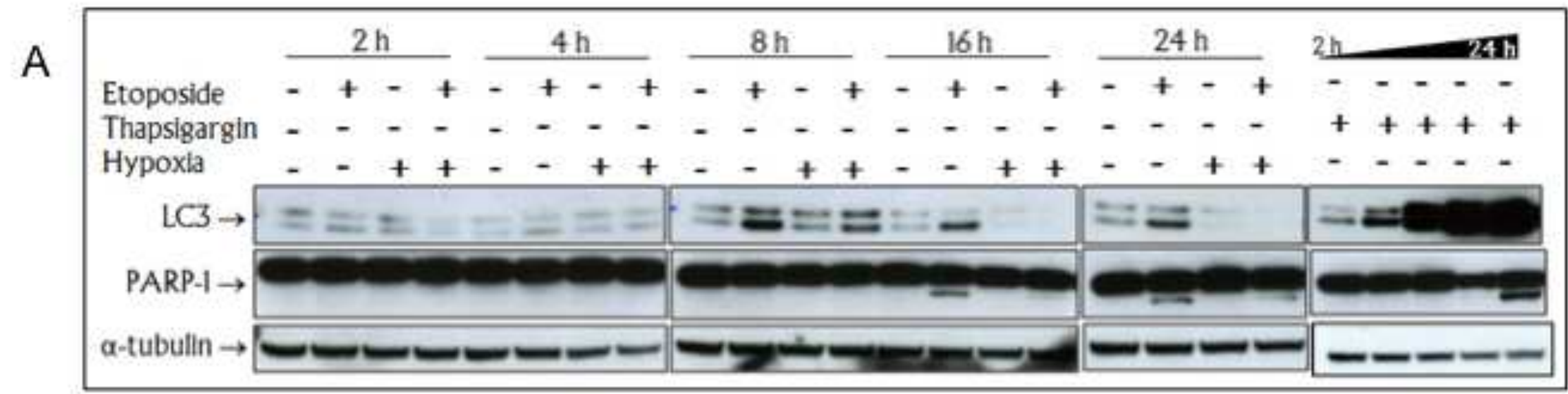
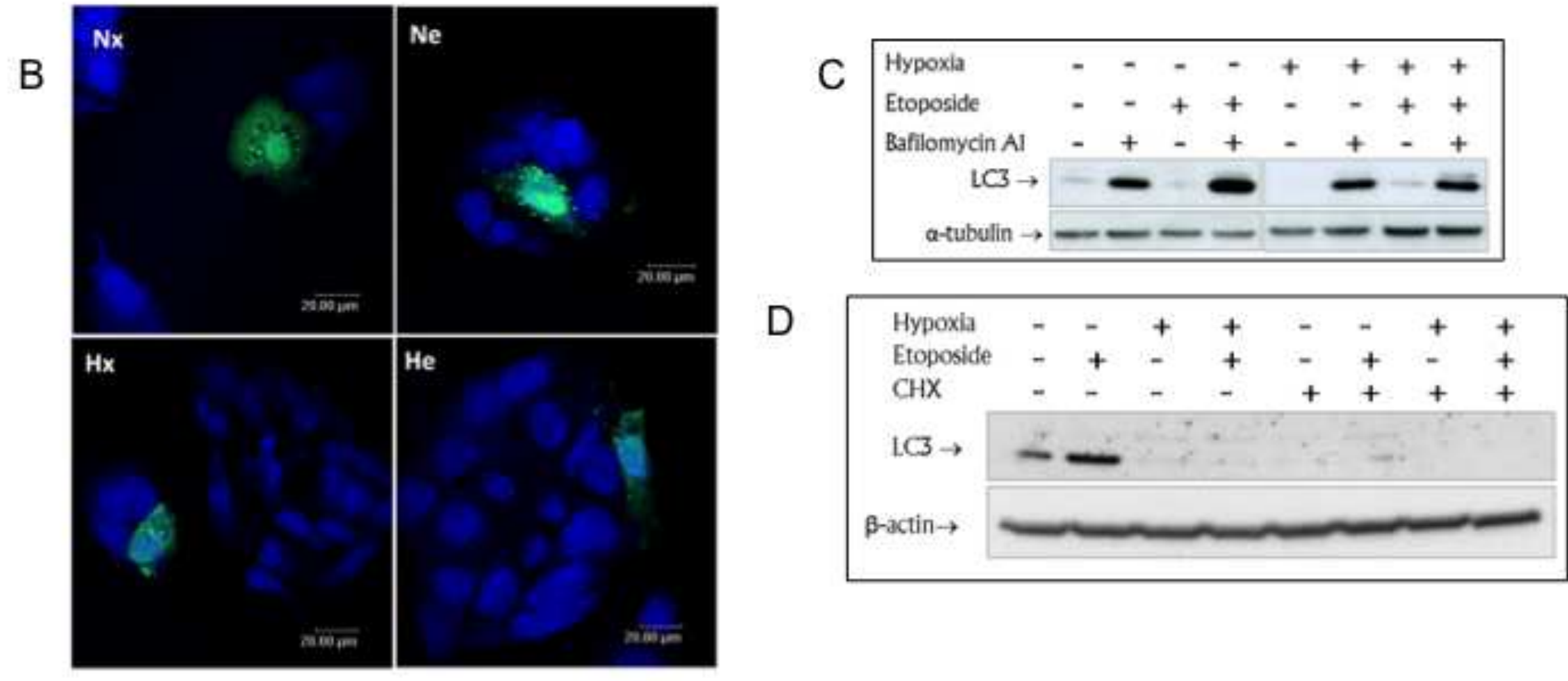

Figure 3 

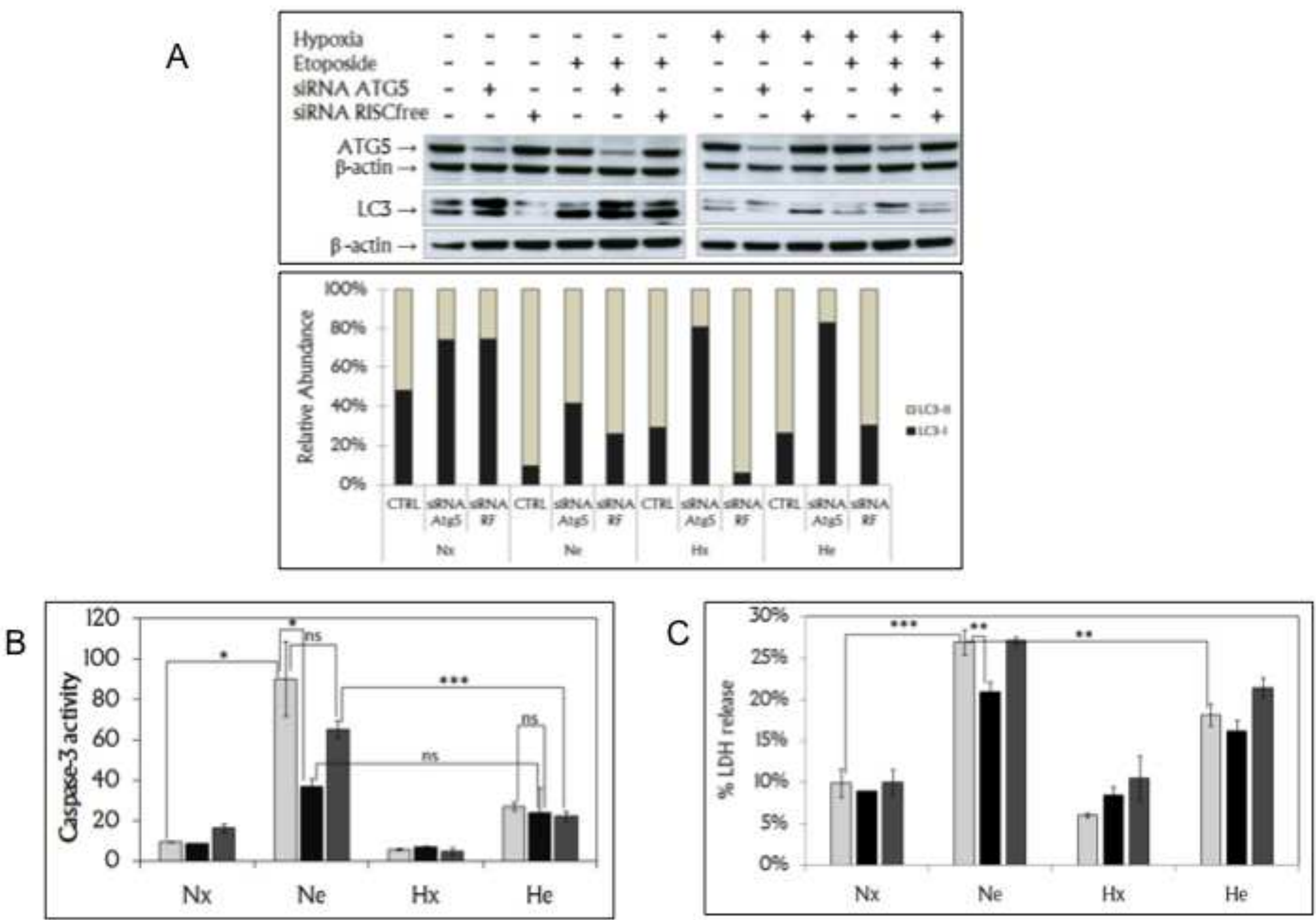

Figure 4

$\square$ Control $\square$ siRNAAtg5

$\square$ siRNA RISCfree 

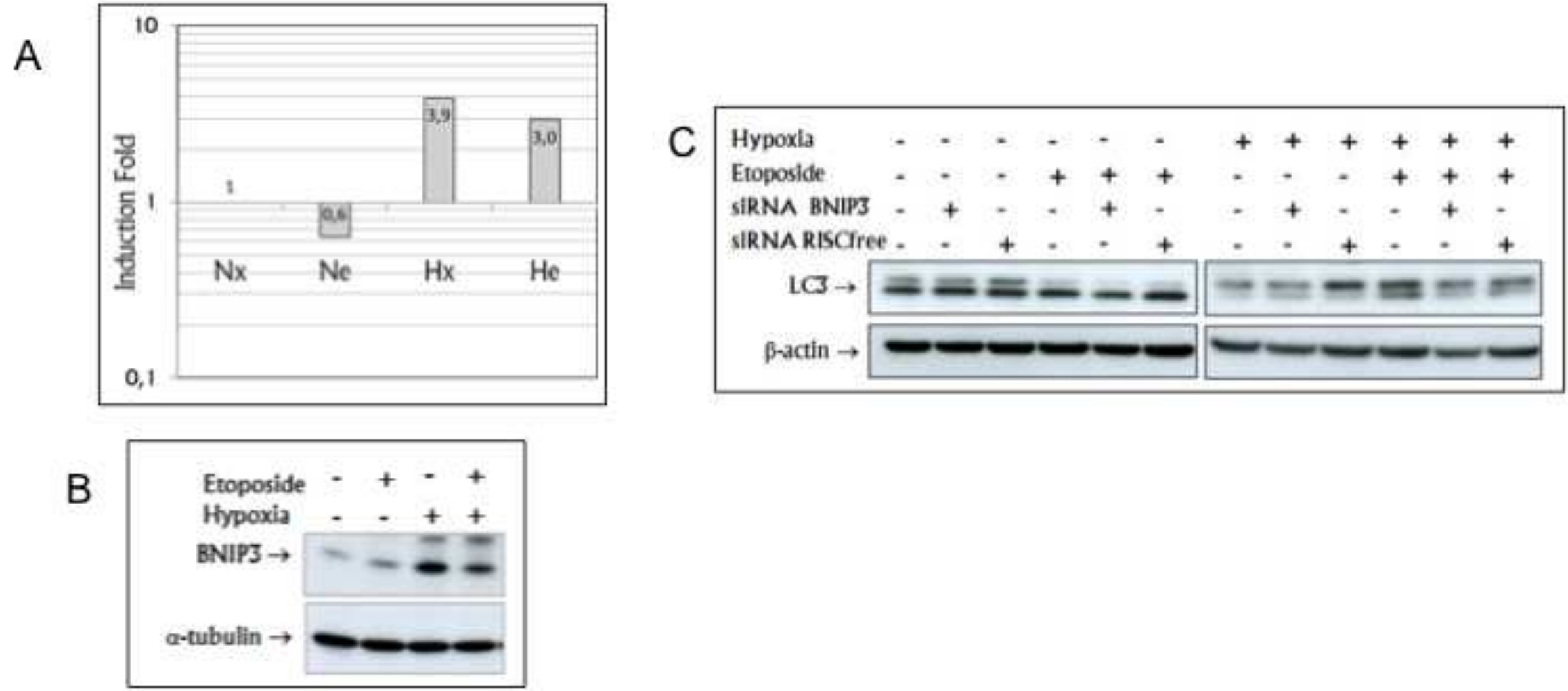

D
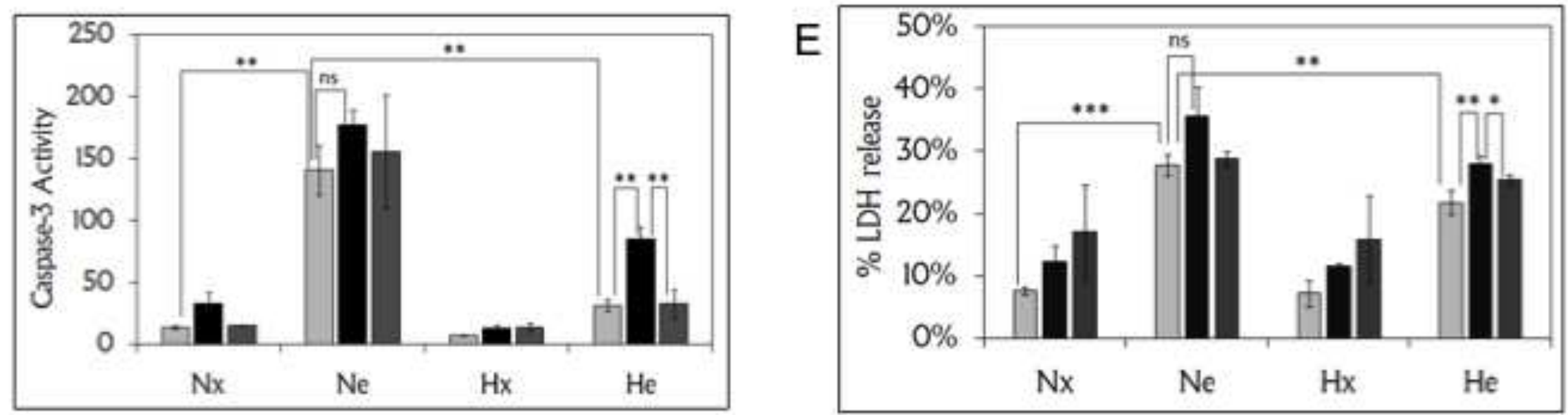

Figure 5

$\square$ Control

$\square$ SiRNA BNIP3

$\square$ siRNA RISCfree 


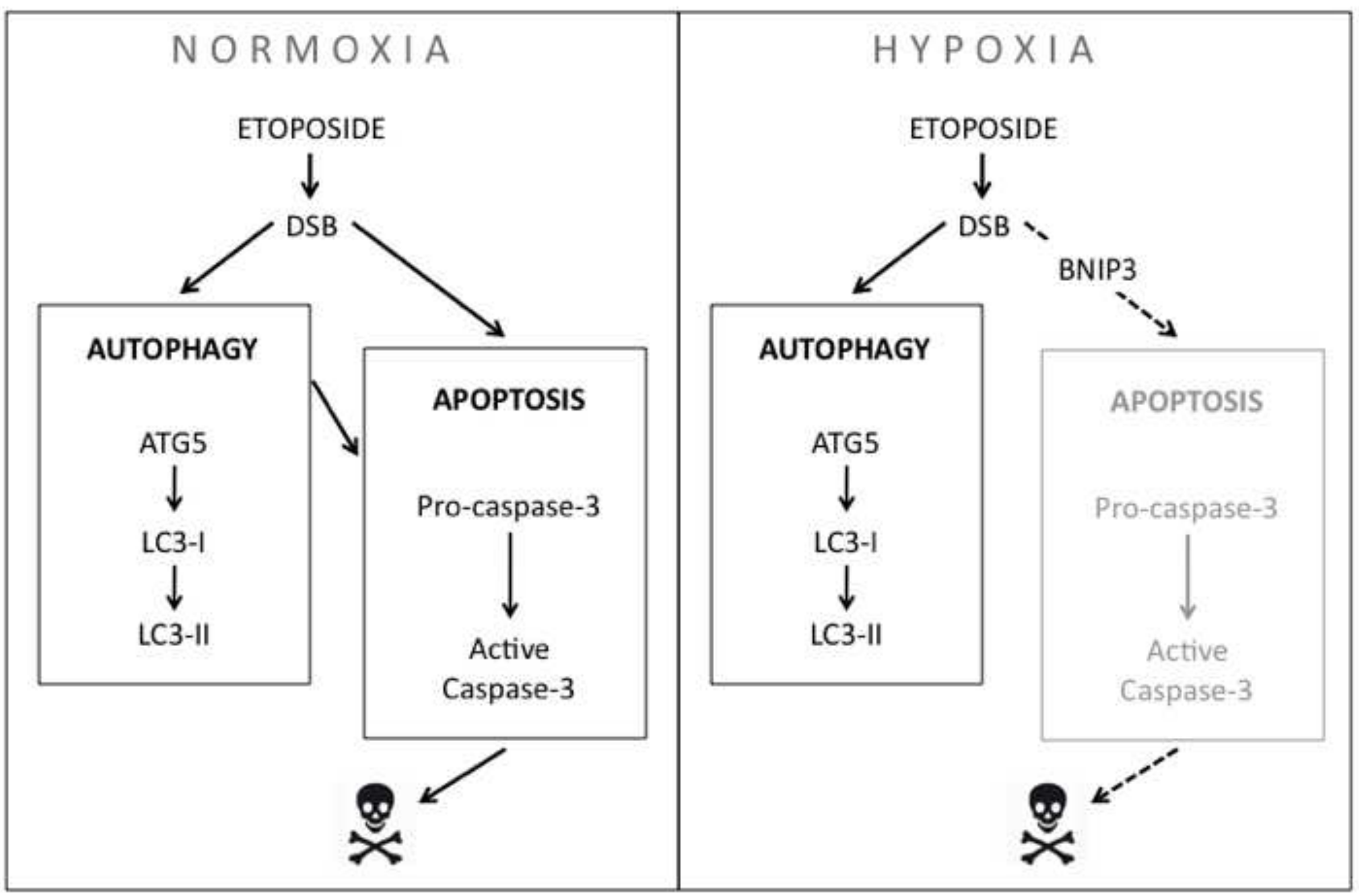

Figure 6 
Etoposide induces cell death through both apoptosis and autophagy. Hypoxia prevents cell death by inhibiting apoptosis in a BNIP3-dependent way without interfering with autophagy.

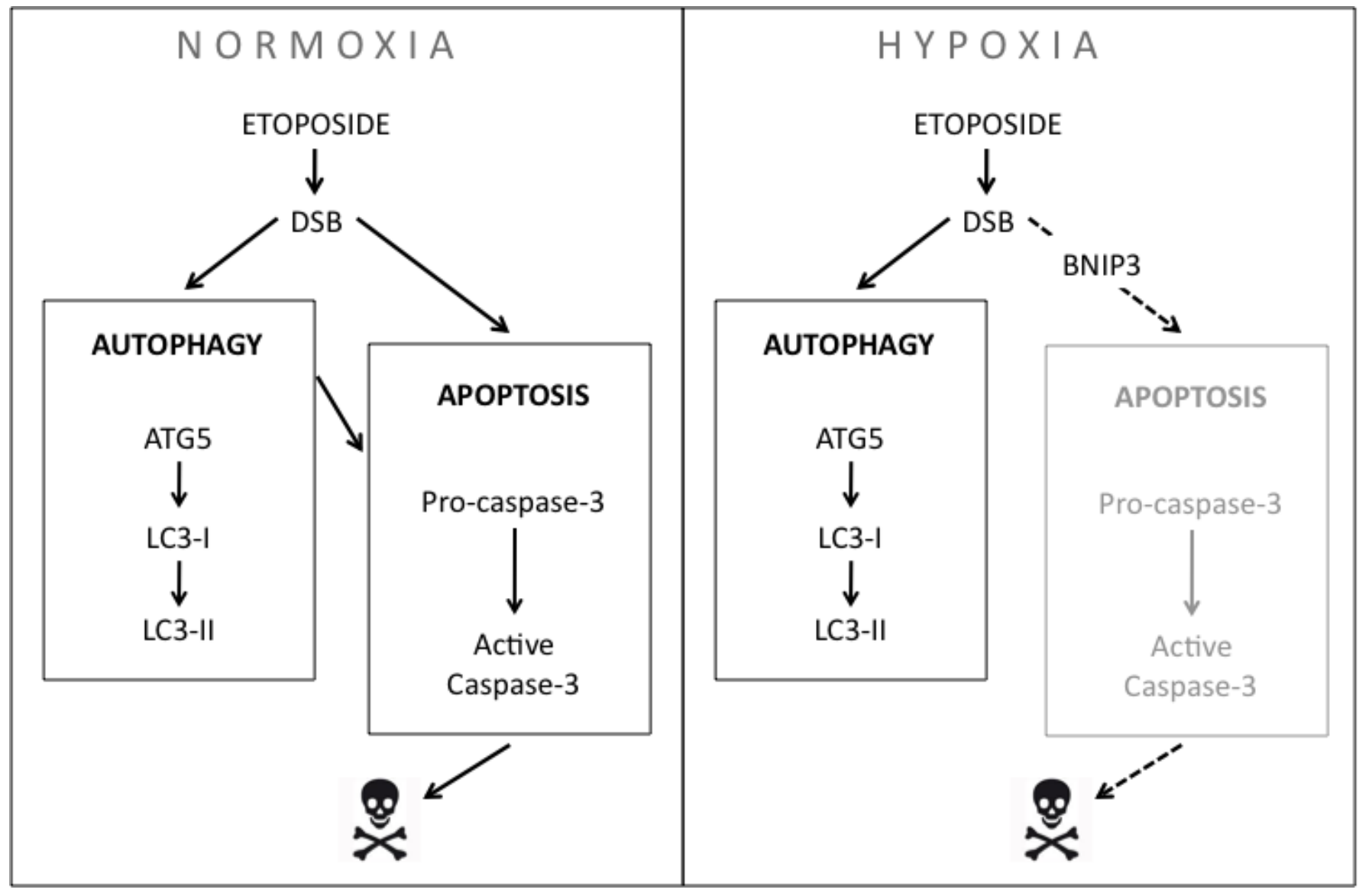

